\title{
MBASAAKÉ IN FAMILY CIRCLE: LINGUISTIC SOCIALIZATION OF POLITENESS IN JAVANESE
}

\author{
Arapa Efendi $^{1}$ Katharina Endriati Sukamto ${ }^{2}$ \\ Ph.D. Student in Applied English Linguistics, Universitas Katolik Indonesia Atma Jaya \& \\ Lecturer, Faculty of Education, Universitas Internasional Batam ${ }^{1}$, \\ Universitas Katolik Indonesia Atma Jaya ${ }^{2}$ \\ arapa@uib.ac.id ${ }^{1}$; katharina.sukamto@atmajaya.ac.id ${ }^{2}$
}

\begin{abstract}
This qualitative preliminary study highlights a common linguistic practice of politeness in the Javanese family circle called mbasaaké, which refers to addressing or referring to a family member with a kinship term that does not necessarily portray the actual family relationship. This study aims to demonstrate that this pragmatic practice of mbasaaké requires the role of adult speakers in the family circle to novice members of the family. The adult members in the family intentionally deployed this act as a strategy to socialize politeness in the Javanese culture. A small number of naturally occurring interactive turns which involves four family members are presented in this paper to illustrate this mbasaaké practice. The four persons who participated in the casual conversations originally come from East Java, but they have resided in Yogyakarta for many years. The data presented in this paper prove that this linguistic socialization is continuously practiced within the family circle with or without the presence of the novice members of the family. Another important finding is that a respectful kinship term is also given to a family member in absentia.
\end{abstract}

Keywords: language socialization, politeness, Javanese, address terms, mbasaaké

\begin{abstract}
Abstrak
Penelitian awal yang bersifat kualitatif ini membahas praktik berbahasa untuk menyatakan kesopanan yang umum digunakan di lingkungan keluarga Jawa yang disebut mbasaaké. Mbasaaké berarti menyapa atau merujuk pada anggota keluarga dengan panggilan kekerabatan yang tidak menggambarkan hubungan keluarga yang sesungguhnya. Penelitian ini bertujuan untuk menunjukkan bahwa praktik mbasaaké ini memerlukan peran orang dewasa dalam lingkungan keluarga kepada anggota keluarga yang lebih muda. Orang dewasa dalam keluarga secara sengaja menggunakan strategi ini untuk menyosialisasikan kesantunan dalam budaya Jawa. Sejumlah percakapan yang melibatkan empat orang anggota keluarga dipresentasikan dalam makalah ini. Keempatnya berasal dari Jawa Timur, tetapi telah cukup lama tinggal di Yogyakarta. Data yang ditampilkan dalam makalah ini membuktikan bahwa sosialisasi berbahasa ini secara terus menerus dipraktikkan dalam lingkungan keluarga dengan atau tanpa kehadiran anggota keluarga yang lebih muda. Teтиan penting lainnya yaitu digunakannya kata kekerabatan untuk seorang anggota keluarga senior yang tidak hadir untuk menunjukkan rasa hormat.
\end{abstract}

Kata kunci: sosialisasi berbahasa, kesopanan, Jawa, panggilan kekerabatan, mbasaaké 


\section{INTRODUCTION}

The following paper attempts to discuss how common linguistic practice in Javanese family circle known as mbasaaké (using proper address forms to a family member with a kinship term that does not necessarily portray the actual family relationship) is deployed by the older family members to socialize politeness to the young Javanese speakers. To do that, the following paper takes the sociopragmatic approach to unveil the role of agency (parents and societal institutions) and other resources (semiotic and cultural) to transmit the "expected behavior" to the young Javanese speakers. The behavior is usually reflected through some of the specific Javanese values such as social manners, respects, and sensitivity towards other people. Leech (1983) describes sociopragmatics as how situational pragmatic meanings reveal the locality of language use. It involves not only the interpretation of meanings in terms of situational perspective, but also includes how certain linguistic practice displays the locality of speech community. The locality that may be associated with what Reiter \& Placencia (2005) refer to as 'norms' rooted in speaker and hearer's meanings being situated and manifested in the speech acts, the structure of conversation, politeness, and 'sociopgramatic variation'. The study is to provide the buoyant view over a great concern on the decline of politeness in Javanese language among the young Javanese generations due to the tendency of parents of using bahasa Indonesia as the national language and the lack of 'intergenerational transmission' of using Krama (Ravindranath \& Cohn, 2014).

As in many other cultures, being polite in Javanese is not simply shown by non-linguistic behavior. It also involves complex linguistic aspects that one should indulge in order to be considered polite by the community. Factors such as social hierarchy and structure, values and norms, beliefs, age, and speaker-hearer relations often determine the choices of words in communicative practices.

In his seminal paper, Poedjosoedarmo (1968) elucidates Javanese politeness as a proper use of language to show respect to those who have higher status and to indicate the degree of formality while speaking to older people and those with whom one does not share close relations. Such linguistic practice is often referred to as the speech levels or 'linguistic stratifications' whereby one form of the language is favored and socially demanded in certain speech situation. Poedjosoedarmo (1968, pp. 57-58) states that the degree of politeness in Javanese is mainly governed by the selection of vocabulary and choice of affixes. For the selection of vocabulary, he classifies four vocabulary types, namely:

1) Ngoko: the words are non-polite and informal, used in communicating with someone who is very familiar with the speaker;

2) Madya: the words are semi-polite and semi-formal, used to express a formality of intermediate degree;

3) Krama: polite and formal words, used in a situation where the relationship between the speaker and the addressee is quite distant and formal; and

4) The fourth type of vocabulary is divided into two:

a. Krama Inggil: words used to refer to highly respected people

b. Krama Andhap: words used to refer to someone's actions toward a highly respected person.

Poedjosoedarmo (1968, p. 58) further exemplifies the four vocabulary types which govern the speech levels: 


\begin{tabular}{cccccc}
\hline English & Ngoko & Madya & Krama & $\begin{array}{c}\text { Krama } \\
\text { Inggil }\end{array}$ & $\begin{array}{c}\text { Krama } \\
\text { Andhap }\end{array}$ \\
\hline $\begin{array}{c}\text { tell/ask to do } \\
\text { something }\end{array}$ & akon & kèn & kèngkèn & dhawuh & ngaturi \\
\hline
\end{tabular}

In a different note, Sudaryanto (1989) argued that the choice of words could indicate a different level of 'affective touch' between the speaker and the addressee (p. 73). For example, the words lunga (Ngoko), késah (Madya), and tindak (Krama), which mean 'go', may lead to different levels of affective touch between the speaker and the addressee when they are not appropriately used. When the three words were not used appropriately, there will be a social consequence in the relationship between the speaker and the addressee. The question Bapak arep lunga? 'Are you going?' addressed to an older or respected person can be interpreted as being inappropriate and rude because it violates the concept of tata krama. As mentioned by Zeitlin et al. (1995) and Subroto et al. (2008), a Javanese social value is captured in, for example, the way to address a second person who is inferior, equal, or above the speaker's rank. For that reason, the question 'Have you eaten?' asked to someone may be expressed in three different ways depending on who the interlocutor is.

\section{Apa kowé wis mangan? (Ngoko) \\ Napa sampéyan pun nedha? (Madya) \\ Punapa panjenengan sampun dhahar? (Krama Inggil)}

Note that kowé, sampéyan, and panjenengan, which mean 'you', should be appropriately used. The choice of verb must also be appropriate. Using the verb mangan 'eat' when talking to an older or respected person will be considered very rude and impolite.

The examples demonstrated above indicate how Javanese speech levels are manifested in daily conversational exchanges and how these levels reflect the culture of unggah-ungguh 'language propriety' (Poedjosoedarmo 2017) to express politeness. This concept is characterized by the four norms or principles, namely (1) social conducts; (2) proper use of speech levels; (3) speaker's relevance to particular speech situations, and (4) good manners.

Sukarno (2010), similarly, describes the three Javanese values in relation to politeness, namely (1) tata krama (possessing particular social manners as dictated by the culture), (2) Andhap-asor (lowering oneself while exalting others), and (3) tanggap ing sasmita (understanding the inference or hidden meaning). Tata krama dictates Javanese people to behave politely according to the standard of the culture. This concept is realized on the language practice through the proper use of speech levels. The value of andhap-ashor requires a person to humble himself/herself while exalting the others. This attitude is also shown by the proper use of vocabulary choice to indicate that the speaker puts himself/herself in a lower position. As for tanggap ing sasmita, a Javanese is expected to understand the hidden meaning of an utterance. Directness is often considered unacceptable by the Javanese, and therefore Javanese language is characterized by many indirect speech acts. A good Javanese native speaker is expected to be good at making inferences. For example, when a guest - after being some time at the host's house - hears the host saying Wah, wis wayahé sholat maghrib (Well, it's time for maghrib prayer). This indirect speech act utterance requires the hearer to make an inference that would meet the intended meaning (illocutionary act). 
While extensive studies have been devoted to detailed description of Javanese speech levels and how such practice gradually declines across younger generations, little attention is paid to a linguistic practice called mbasaaké, which refers to the use of address form to a family member which does not really show the exact line of the family hierarchy. In Javanese family circle, parents tend to use a polite address term when speaking to a younger person that holds a lower status in family structure. To give an example, parents often address their children with Mas 'older brother', Mbak 'older sister', or Dik 'younger brother/sister' rather than their first name or nickname. In this context, parents place themselves at a lower family structure by the choices of address terms to the children. This 'acceptable irregularity' is actually intended to socialize and familiarize the culture of unggah-ungguh 'language propriety' (Poedjosoedarmo 2017) to the young family members.

In this paper, we would like to highlight this commonly pragmatic practice in the Javanese family circle, which describes how the Javanese community applies this situated politeness. Apparently, this linguistic behavior has been passed down from generation to generation and socialized in the family circle. Samples of interactions presented in this paper are limited to a number of daily conversations among four Javanese family members that took place in Yogyakarta. The persons involved in the casual conversations originally come from East Java, but they have resided in Yogyakarta for many years. Many of the words were expressed in the Ngoko speech level, although some were in the higher form to indicate that the speakers put himself/herself in a lower position. However, choice of vocabulary which indicates speech levels will not be discussed here as it is beyond the scope of this study.

\section{LITERATURE REVIEW}

\section{Language Socialization and Agency}

Language is used as a social and cultural instrument that allows us to behave or perform an act in socially and culturally appropriate ways. Ochs \& Schieffelin (1986) assert that older or senior members of a family or society are supposed to socialize particular cultural values and beliefs to the younger members through the use of language. In this perspective, language is seen as a primary medium for passing down the inherited values and beliefs to the youths. In other words, the senior members here play the role as the agents of language socialization.

Ochs and Schieffelin (2011) further mentioned two features of language socialization. First, it is an analytic focus on speech, writing, gesture, images, music, and other signs as means of the socialization process. Second, it involves 'ethnographic sensibility' that accounts for the socialization force of these semiotic resources (bodies, symbols, material objects, and surrounding environments) in driving and transforming meaningful sociocultural practices, events, relationships, emotions, situations, moralities, and ideologies. Language and other possible semiotic resources are crucial in the reproduction of social order, and cultural knowledge, beliefs, values, ideologies, symbols, and indexes. The linguistic properties that play a role in the reproduction of these aspects involve grammar (evidentials), lexicons (kinship terms), phonology (intonations), speech acts (directives), conversational sequences, genres, channels, and codes.

Through social interaction, the learner is expected to perform a particular verbal interaction in a cultural setting (Lee \& Bucholtz, 2015). This reflects the top-down relationship where the socialization is controlled, directed, and instituted from the top level (of the experienced adults/parents/senior societal members) to the younger persons. The input of socialization is also 
embedded not only in the informed person, but also the artifacts, and established environments. All these sources of input work together in order to encourage the internalization of the cultural values and beliefs by novice members as they participate in meaningful verbal interactions.

Language socialization also embraces the locality of the values and norms of one's own culture. This suggests that children are not only expected to become the speakers of languages but also the speakers of cultures (Ochs \& Schieffelin, 2011). The children, through language socialization practice, are expected to represent the values and beliefs of their culture. In order to do so, children are often situated in sociocultural meanings where the cultural and social localities are presented to them. As language is used a tool to socialize cultural norms, values, and beliefs, then adult speakers are supposed to pass on the cultural meanings to the novice members.

Language socialization has strongly been applied in the Javanese community. SmithHefner (1998a, 1998b) has raised the issue that Javanese children are normally exposed to the forms they are expected to use. Wolf \& Poedjosoedarmo (1982), similarly, also claim that Javanese children are motivated by their parents' aspiration to raise their children in "good breeding, self-control, and inner-balance", so that they are able "to maintain good interpersonal relationships" (p.169) with other people. This aspiration later motivates not only parents but also other family members to participate in socializing such expected values in the family circle. Therefore, in order to raise children with the expected polite linguistic behavior, the principle of unggah-ungguh should be passed down through the practice of using appropriate speech levels.

\section{Kinship Address Terms in Javanese}

Addressing or referring to someone in the family circle normally indicates positive politeness which shows closeness and solidarity (Brown \& Levinson, 1987), but at the same time also power in the family hierarchy. The use of kinship address terms, especially in speech, commonly involve nicknames (or first names) ${ }^{\mathrm{i}}$ as well as those terms which demonstrate the hierarchical status between the speaker and the addressee (e.g. Mom, Dad, Uncle, Auntie, Grandpa, Grandma, etc. in English).

Unlike in English, the kinship address terms in Javanese are more complex and varied. Geertz (1989) classifies the Javanese family structure into four categories, as in Figure 1 below. 


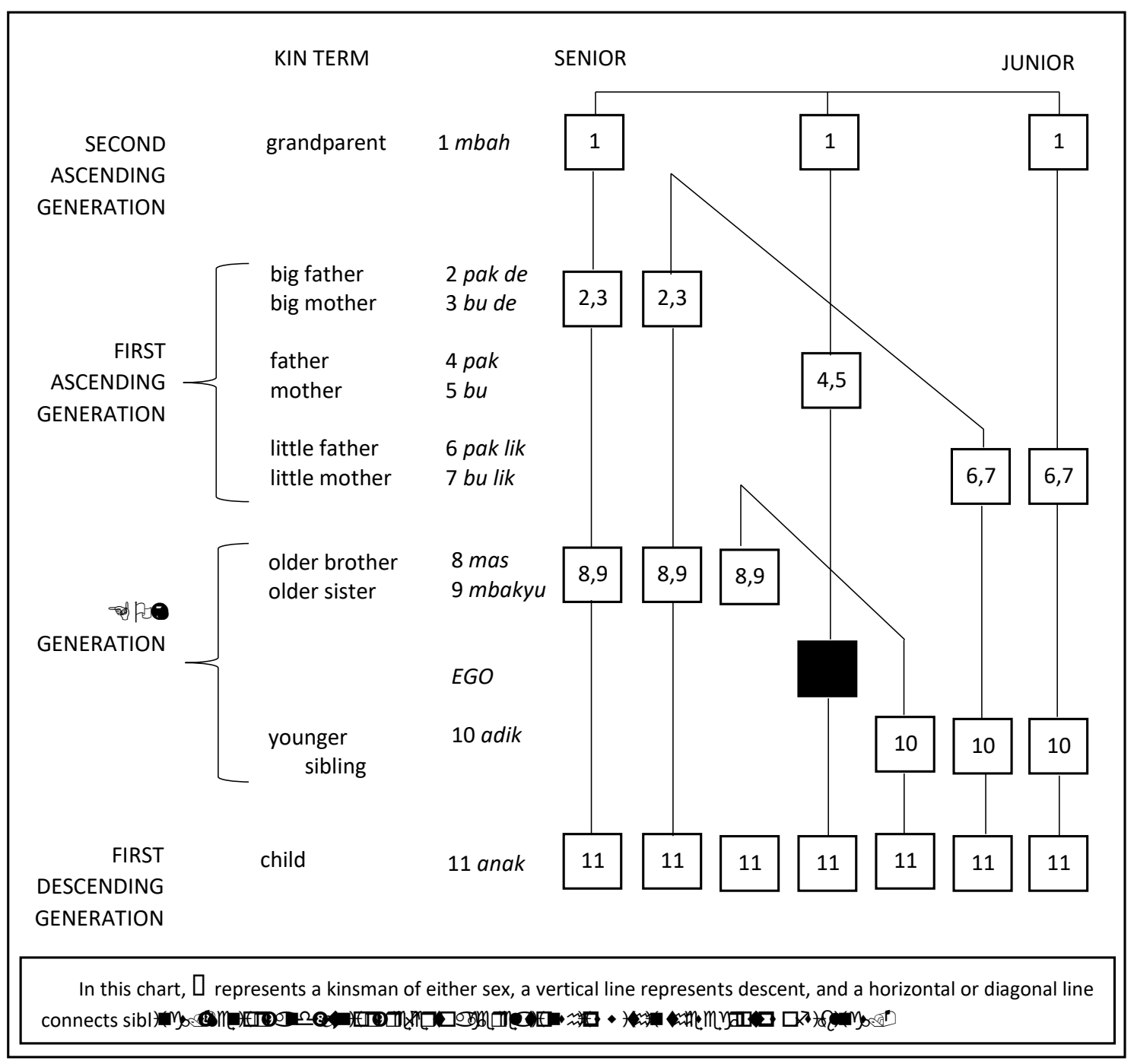

Figure 1. System of Javanese Kin Terms (Geertz, 1989, p. 17)

Geertz (1989) describes that seniority plays an important role in Javanese kinship system. The ego's generation includes the ego's siblings: mas 'elder brother' and mbak 'elder sister'. Adik is the ego's younger siblings. The upper generation of the ego is the first ascending generation, while the two older generations are the second ascending generation of the ego, which includes the ego's grandparents and the grandparents' siblings. The lower generation of the ego, or the first descending generation, is comprised of the ego's child or children. Big father and big mother here refer to the elder brother ( $p a k$ dhé) or elder sister ( $b u$ dhé) of the ego's father or mother, respectively. Little father (pak lik) and little mother ( $b u$ lik) refer to the younger siblings of the ego's parents.

Geertz's classification denotes that the upper categories should receive high respect which is shown in the choice of speech levels. The ego is thus expected to appropriately apply the 'linguistic etiquette' (Norwanto 2016, p. 49), whether he/she should use Ngoko, Madya, or Krama to the family members. Parents, parents-in-law, grandparents, as well as the siblings in the upper generations should be attributed with a deference position. 
In terms of the Javanese kinship terms, Robson (1987) presents a comprehensive terminology which includes three generations of patrilineal lines. However, for the purpose of this study, we would limit the description of Javanese kinship address terms which are commonly used among family members in the areas of Yogyakarta and Surakarta. Note that some other areas in Java may have different kinship terminology.

Table 3. Javanese Kinship Terms Indicating Title

\begin{tabular}{ll}
\hline \multicolumn{1}{c}{ Address/title } & \multicolumn{1}{c}{ English equivalence } \\
\hline Bapak / Pak & Father \\
\hline Ibu / Bu / Mbok & Mother \\
\hline Pak dhé / Dhé & Uncle (parents' older brother) \\
\hline Bu dhé / Dhé & Aunt (parents' older sister) \\
\hline Pak lik / Lik & Uncle (parents' younger brother) \\
\hline Bu lik/Lik & Aunt (parents' younger sister) \\
\hline Kang mas / Kang / Mas & Older brother \\
\hline Mbakyu / Mbak / Yu & Older sister \\
\hline Adik / Dik & Younger (brother/sister) \\
\hline Mbah Kakung / Éyang Kakung / Kung & Grandfather \\
\hline Mbah Putri / Éyang Putri /Uti & Grandmother \\
\hline Tolé / Lé & Son \\
\hline Genduk /Nduk & Daughter \\
\hline
\end{tabular}

The practice of njangkar 'calling a person by his/her name without title' in Javanese may be applied to kids or when the participants have a very close relationship. This practice may be quite sensitive since it may indicate disrespect and improper behavior (Norwanto, 2016). This practice may also be interpreted as a negative attitude which indicates a certain disrespect to the interlocutor (Wolff \& Poedjosoedarmo, 2002).

With regard to types of participants, Norwanto (2016) pointed out that respect should also be demonstrated to a referent who is not present in a conversation. Those who are present in the conversation are expected to treat the person in absentia as if he/she were present. In this case, the speaker and hearer should recognize the social status of the person in absentia. The relation between the speaker, the hearer, and the person in absentia is illustrated in Figure 2. In relation to kinship referential expressions, the use of in-absentia referring expressions may affect the person's identity or position in the family (Norwanto, 2016).

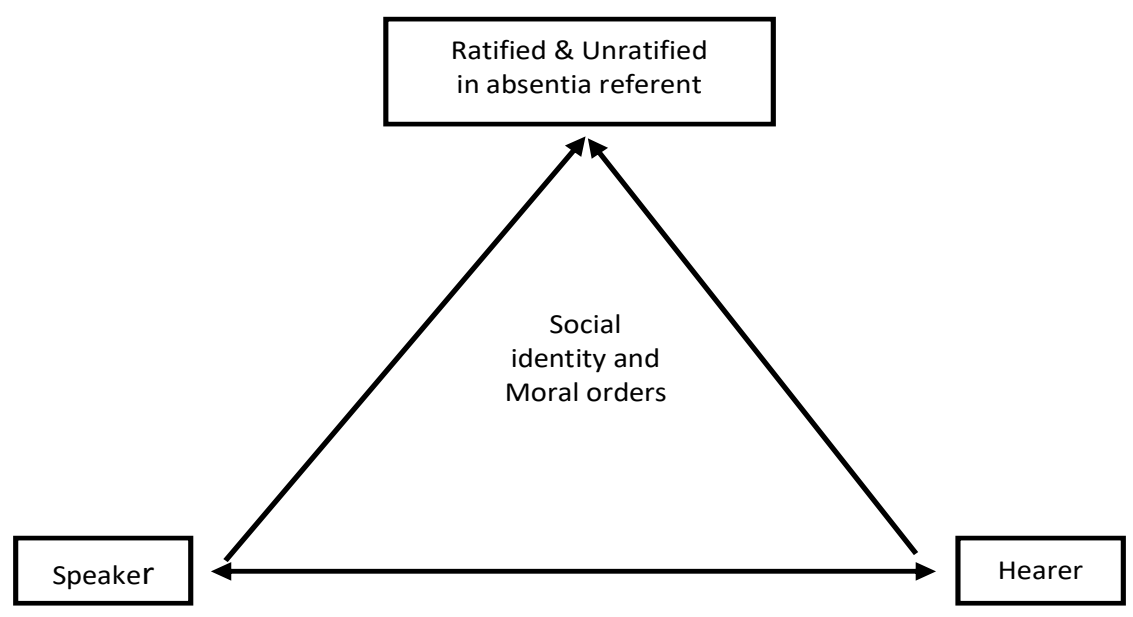

Figure 2. Relation of Participants in a Conversation (Norwanto, 2016, p. 71) 


\section{METHODOLOGY}

\section{Participant Profiles}

The recorded interactions involve four members of a Javanese family in different situational contexts and communication goals. As for the privacy issues, the names of the participants are given in Javanese pseudonyms.

Bardi: 70 years old, born and grew up in Bojonegoro, East Java. He is the head of the family with three children and one participant (Diah) is one of the children living with him while the other two living apart from him. He married to a woman from Solo, but both spent lives together mostly in Yogyakarta, Semarang, and Malang. Bardi is a retired police chief commissioner having the assigned duties in Pontianak (West Kalimantan) for three years, Purwodadi (Central Java) for three years, Yogyakarta for five years, and Semarang until his retirement. His language is not only affected by the east Javanese dialect, but is also influenced by central Javanese dialect which might be due to his years of experience living among the Javanese communities in Semarang, Purwodadi, and Yogyakarta.

Nono: 58 years old, born and grew up in Bojonegoro, he is the youngest brother of Bardi or uncle to Diah, Bardi's youngest daughter. Unlike Bardi, Nono finished high school and has worked as parking attendant in a private school in Bojonegoro. His dialect reveals the domination of East Javanese as he works and lives in Bojonegoro with little travel experience to other regions.

Diah: 34 years old, born in Malang and grew up in Yogyakarta. She is the youngest child of Bardi and she married to a man from Kalimantan but currently lives with her father in Yogyakarta. Diah has been living in Yogyakarta since her childhood, but she once relocated to Malang before going back again to Yogyakarta. She has been exposed to two Javanese dialects, the east Javanese and central Javanese. In the family circle, she uses bahasa Indonesia to her husband and the nonstandard Javanese to her father. It is not her inability or impoliteness that backgrounded her frequent use of ngoko to her father (which might be considered impolite behavior), but this is due to language socialization in her family circle that she was not exposed to polite form of Javanese dialect (as mostly used by younger members of the family in Yogyakarta when speaking to elders).

Lisa: 43 years old, born and grew up in Yogyakarta. She is the daughter-in-law of Bardi and sister-in-law to Diah. She earned a diploma in tourism and currently works as a dressmaker in Kalasan, Yogyakarta. Unlike the other participants in the study, Lisa is the only participant who was born and grew up in Yogyakarta, and that is why she speaks with a central Javanese dialect.

\section{Instrument and Data Collection}

For the purpose of data gathering, we made use of a voice recorder. This device is used to record the naturally-occurring conversations among the family members. The audiotaped conversation enables us to preserve data in the digital format, and with the data of this type we can always get back to have a thorough analysis on the interaction between participants. The spoken data were transcribed by one of the authors. 


\section{Data Analysis}

After transcribing the spoken data, all kinship address terms were coded and their uses were analyzed based on the theoretical approach of language socialization (Ochs \& Schieffelin, 2011) and Javanese kinship system (Geertz, 1989; Norwanto, 2016).

\section{FINDINGS AND DISCUSSION}

Based on the available limited data, we found a number of mbasaaké practice in the conversations among the family members. Bardi, being the oldest and most respectful person in the family, was the only one who practiced njangkar 'calling by the name' to his younger brother Nono. However, Nono did not address his older brother as Mas or Mas Bardi, but used De (a variant of Pak De 'uncle') instead, as can be seen in the following.

\section{Excerpt 1}

Bardi: Wah yo macet, No.

(The traffic must have been bad, No.)

Nono: Muaceeet men. Sepéda motor iso ngéné ngéné to Dé.

(It was really bad. The motorbikes were this... this (demonstrating motorbikes finding their ways), Dé.

Excerpt (1) is a conversation between Bardi and his younger brother Nono. It is interesting that Bardi did the practice of njangkar, but Nono, being a junior, addressed his older brother with the Javanese kinship term Dé (short form of Pakdé 'uncle'), as if he was positioning himself as Diah, Bardi's daughter. By addressing his older brother as Dé, Nono lifted his brother into a higher position and at the same time positioned himself in a lower position in the family hierarchical structure.

In this family circle, it seems that Nono was quite consistent in addressing his older brother as Dé. It may be assumed that he initially practiced this in front of his children to socialize the Javanese linguistic politeness, and then this practice became a kind of 'habit' in the daily interaction. The following is another example.

\section{Excerpt 2}

Nono: Jam piro Pak Yanto njupuk keris, Dé. Sore?

(What time will Mr. Yanto take the kris, Dé? This evening?

Bardi: Maghrib.

(After sunset)

Interestingly, Bardi, who plays the role as the father and grandfather in the family, referred to himself as Kung (variant of Éyang Kakung 'grandfather') to his daughter Diah. Similarly, Diah also used the same kinship expression. Observe the following conversation.

\section{Excerpt 3}

Diah: Kung, Putra arep nyilih kamaré nggo sinau online

(Grandpa, Putra (Diah's son) wants to use your room for online class)

Bardi: Yo wés, kono. Dinggo waé. Anu, sisan jupukké hapéné Kung yo. Ngko nèk wés mulai sinau répot njupuké. 
(Yes, that should be fine. Just use it. Meanwhile, could you grab grandpa's phone because it will be difficult to take it when he starts learning)

This kind of 'irregularity' can be interpreted as a cultural socialization for Putra, who is a novice member in the family. In this case, both Diah and Bardi can be regarded as the agents in socializing the cultural value. The way Bardi used Kung as a referring expression for himself seems to be quite consistent, as can be seen in the following dialogue.

\section{Excerpt 4}

(a) Bardi: Mbah kung biyèn nèk mimik kopi ora gelem nèk dudu gawéané ibué mbah

\section{kung.}

(In the past, grandpa used to drink coffee only if it was made by the mother of grandpa)

(b) Diah: Kok iso kenopo Kung?

(Why, Grandpa?)

(c) Bardi: Ya iya nèk lagi dolan ndok Jogja mesti nggowo kopi seko omah.

(Yes, she used to bring her own coffee from home when traveling to Jogja)

(d) Diah: Emang kopiné piyé Kung?

(What is so special about the coffee, Grandpa?)

Excerpt (4) shows that Bardi used the kinship reference Mbah kung (grandfather) when he talked to his daughter. Diah also consistently used the kinship term Kung although her son was not present.

Another example of mbasaaké practice is shown in Excerpt (5), a conversation between Bardi and his daughter-in-law (Lisa). Mas Arif, the person Bardi was looking for, is Lisa's husband or Bardi's son. Note that Bardi did not address his son with his name, but he adds Mas 'older brother' despite the fact that he is Arif's father.

\section{Excerpt 5}

\section{Bardi: Mas Arif ndi?}

(Where is Mas Arif?)

Lisa: Dèrèng wangsul. Tasih ten bèngkèl.

(He hasn't arrived yet. He's still in the workshop.)

As we can see in the first line in Excerpt (5), Bardi asks if his son, Arif, has arrived home to Lisa (Arif's wife). Instead of using the proper name to refer to his son who holds a lower family structure in the family, Bardi uses a combination of kinship term of address and proper name (Mas + Arif). The word Mas in Javanese literally means 'older brother' while in fact Bardi is the father of Arif. By doing this, Bardi applied the mbasaaké practice for the purpose of socializing polite address terms in the family circle.

Another example is how Bardi referred to his wife as Éyang Nanik, who at the time of speech was in Jakarta and was about to go back home to Yogyakarta. Those who were present during the conversation were Diah (Bardi’s daughter) and Lala (Bardi's grandchild). 


\section{Excerpt (6)}

Bardi: Cepet reresik, Éyang Nanik mréné omahé wés iso blong ngono.

(Be quick to clean (the house), when Grandma Nanik comes, the house is tidy.)

The topic of the conversation in (6) is about the arrival of Eyang Nanik, Bardi's wife from Jakarta. During the conversation, there were Lala (Bardi's grandchild) and Diah (Bardi's daughter) as the passive participants sitting around the living room. In this case, although Bardi's wife was not present, he recognized her hierarchical status by using the referential expression Éyang Nanik 'grandma Nanik'. As mentioned by Norwanto (2016), this act is quite normal in Javanese, as the participants in a conversation should recognize the status of the person in absentia. However, it should be noted that it is not clear why Bardi used Éyang 'grandpa/grandma' as a referring expression for his wife, whereas he used mbah 'grandpa/grandma' for himself (see Excerpt (4)). Although both mbah and éyang have the same meaning, éyang is considered as the Krama variety and is mostly used to refer to an elderly person from the priyayi 'royal descendant' community or 'white-collar workers' (Geertz 1989). This issue is beyond the scope of this study and therefore will not be discussed.

As mentioned by Ochs \& Schieffelin (2011), there should be two actors in language socialization, the older ones as the experts and the younger ones as the novice. This unequal relationship reflects the top-down association whereby the socialization of the politeness is controlled, directed, and instituted from the top level (the experienced adults/parents/senior societal members) to the lower group perceived as the 'novice'. Excerpt 7 again demonstrates that all members of the family consistently perform the act of mbasaaké.

\section{Excerpt 7}

Diah: Kadisuko ki rung tau weruh aku. Mbah Kung wés tau rono?

(I don't know Kadisuko Temple. Have you been there, grandpa?)

Bardi: Urung.. cilik kétoké candiné. Yo mlebu kui to néng pemancingan.

(I haven't been there. The temple looks very small, you can go there via the nearby fishing spot.)

Diah: Nèk Sambisari iku digawé koyo tempat upacara atau opo kok samono? Wingi tekan ngisor Mbah Kung?

(I was wondering if Sambisari (temple) is used for ceremonials? Did you go down, grandpa?)

Bardi: Ora, Eyang Nanik ra gelem

(No, grandma Nanik was not willing to go down.)

Diah: Ooo.. nang dhuwur tok

(So, you two just wandered around the temple?)

Bardi: Nek Lala kan tekan ngisor

(Lala did go down to the first floor, didn't she?)

Diah: Heeh tekan ngisor

(Yes, she went to the floor of the temple.) 
The dialogue in (7) is between Diah and her father (Bardi) that took place sometime in the evening in the living room. Lala and Putra, Diah's children, were present in the conversation. The topic of the conversation is about the experience of Bardi and Nanik when visiting a temple. Referring to Ochs \& Schieffelin (2011), the adult experts in this case are Bardi and Diah, and the novice members were Putra and Lala. Note that Bardi did not use any kinship marker for Lala, the youngest member in the family. Note also that Eyang Nanik (Bardi's wife) consistently received a respectful reference despite the fact that she was a person in absentia.

Mbasaaké does not present us with actual kinship relations. Javanese speakers are normally aware in choosing a kinship referential expression for the person s/he is talking to. This selection is dictated by the concept of tata krama 'appropriate manners', which leads Javanese speakers to behave and speak politely according to the proper standard of the culture. This tata krama value is commonly passed on from generation to generation by socializing it to novice members in the family.

\section{CONCLUSION AND RECOMMENDATION}

Mbasaake is a socio-pragmatic concept in Javanese that requires the role of agency. The adults as the experts act as the agents to socialize the polite address kinship terms to the novice members. In the Javanese community, politeness should be seen as a situated practice by which the norms and values are dictated by tata krama which involves an asymmetrical relation between the older members and the younger members. The younger members are continuously exposed to meaningful communicative practices to extract knowledge and experience as they are socialized with the norms and values that are embedded in the linguistic choices and codes by the adult members.

This paper has highlighted the mbasaaké practice performed by four Javanese people living in Yogyakarta. The data indicate that kinship reference does not always portray the actual family relationship, instead some acceptable violation over the use of the address terms is intended for the purpose of socializing polite reference to the novice members of the family hence we suggest the term 'acceptable irregularity' as the form of socializing polite kinship (or address) reference. The data presented in this paper show that the linguistic socialization is continuously practiced by the adult speakers with or without the presence of the novice members of the family. Furthermore, a respectful kinship referring expression is also given to a family member in absentia.

\section{NOTE}

The authors would like to thank the four participants involved in this study for their generous support throughout the initial stage of the study. We would also like to give special thanks to Dr. R. Kunjana Rahardi for his valuable suggestions during the completion of the paper.

\section{REFERENCES}

Brown, P. \& Levinson, S.C. (1978). Politeness: Some universals in language usage. Cambridge, England: Cambridge University Press. 
Brown, P. \& Levinson, S.C. (1978). Universals in language usage: Politeness phenomena. In Goody, Esther N. (eds.), Questions and Politeness, 56-289. Cambridge: Cambridge University Press.

Brown, P. \& Gaskins, S. (n.d.). Language acquisition and language socialization. The Cambridge Handbook of Linguistic Anthropology, 187-226. doi:10.1017/cbo9781139342872.010

Brown, P. \& Levinson, S.C. (1987). Politeness: Some universals in language usage. Cambridge: Cambridge University Press.

Geertz, H. (1989). The Javanese family: A study of kinship and socialization. Illinois: Waveland Press.

Lee, J.S. \& Bucholtz, M. (2015). Language socialization across learning spaces. In N. Markee (ed.) The handbook of classroom discourse and interaction. John Wiley \&Sons, Inc., 319336.

Leech, G.N. (1983). Principles of pragmatics. London: Longman. In LoCastro V. (2012). Pragmatics for language educators: A sociolinguistic perspective. New York: Routledge.

Norwanto, N. (2016). Gender and politeness in Javanese language. Unpublished doctoral thesis, University of Huddersfield. http://eprints.hud.ac.uk/id/eprint/34162/

Ochs, E. (2002). Becoming a speaker of culture. In Kramsch, C. (Ed). Language acquisition and language socialization: Ecological perspectives (pp. 99-120). New York: Continuum.

Ochs, E. (1996). Linguistic resources for socializing humanity. In J. Gumperz, \& S. Levinson (Eds.), Rethinking linguistic relativity (pp. 407-437). Cambridge: Cambridge University Press

Ochs, E. \& Schieffelin B.B. (1986). Language socialization. Annual Review Anthropology, 15: 163-191.

Ochs, E. \& Schieffelin, B.B. (2011). The Theory of Language Socialization. The Handbook of Language Socialization, 1-21. doi:10.1002/9781444342901.ch1

Poedjosoedarmo, S. (1968). “Javanese Speech Levels” in Indonesia No. 6 (Oct. 1968) Southeast Asia Program Publications at Cornell University, pp. 54-81. http://about.jstor.org/terms.

Poedjosoedarmo, S. (2017). Language propriety in Javanese. Journal of Language and Literature, 17(1), 1-9.

Ravindranath, M. \& Cohn, A.C. (2014). Can a language with millions of speakers be endangered? Journal of the Southeast Asian Linguistics Society 7, 64-75.

Reiter, R.M. \& Placencia, M.E. (2005). Research methods in Sociopragmatics. In Spanish Pragmatics. Palgrave Macmillan, London.

Robson, S. O. (1987). The terminology of Javanese kinship. Bijdragen Tot de Taal-, Land- En Volkenkunde / Journal of the Humanities and Social Sciences of Southeast Asia, 143(4), 507-518. doi:10.1163/22134379-90003317

Smith-Hefner, N.J. (1988a). The linguistic socialization of Javanese children in two communities. Anthropological Linguistics (30(2), pp. 166-198.

Smith-Hefner, N.J. (1988b). Women and politeness: The Javanese example. Language in Society, Vol. 17(4), 535-544. 
Subroto, D.E., Dwirahardjo, M., Setiawan, B. (2008). Endangered Krama and Krama Inggil: Varieties of the Javanese language. Linguistik Indonesia 26(1), 89-96.

Sudaryanto. (1989). Pemanfaatan potensi bahasa: Kumpulan karangan sekitar dan tentang satuan lingual bahasa Jawa yang berdaya sentuh inderawi. Seri ILDEP. Yogyakarat: Kanisius.

Sukarno. (2010). The reflection of Javanese cultural concepts in the politeness of Javanese. Jurnal K@ta. Vol. 12(1), 59-71.

Wolff, J. \& Poedjosoedarmo, S. (1982). Communicative codes in Central Java. Linguistic series VIII, data paper, no 116: Southeast Asia programme, Department of Asian Studies, Cornell University. In Smith-Hefner, N.J. 1988. The linguistic socialization of Javanese children in two communities. Anthropological Linguistics (30(2), 166-198.

Wolf, J. \& Poedjosoedarmo, S. (2002). Communicative codes in Central Java. New York: SEAP.

Yang, X. (2007). Address forms of English: Rules and variations. Journal of Language Teaching and Research, 1(5), 743-745.

Zeitlin, M.F., Megawangi, R. Kramer, E.M., Colletta, N.D., Babatunde, E.D. \& Garman, D. (1995). Strengthening the family: Implications for international development. Tokyo: United Nations University Press. 